\title{
О способах и средствах выражения гнева в русской языковой картине мира
}

\author{
А. Е. БОЧКАРЕВ \\ Департамент литературы и межкультурной коммуникации, \\ Национальный исследовательский университет «Высшая школа экономики», \\ ул. Большая Печерская, д. 25/12, RU-603155 Нижний Новгород \\ E-mail: bochkarev.andrey@mail.ru
}

(Received: 9 October 2016; accepted: 3 January 2017)

\begin{abstract}
This paper explores the ways of displaying anger in the Russian linguistic image of the world. According to the National Corpus of the Russian Language, anger dims eyes, makes blind and mad. In metaphorical projections, anger is defined in relation to the structural elements of other subject areas, including fluid, wild animals, natural disasters, fire, lightning, or thunderstorm. By analogy with some resources, anger is collected, wasted, and exhausted; by analogy with water, anger overflows and boils; by analogy with fire, inflames, and fades, anger can flare up and fade; by analogy with wild animals, it can be curbed, tamed, or subdue. It is quite common that speakers do not pay attention to metaphorical expressions but take them almost for the objective characteristic of anger.
\end{abstract}

Keywords: emotions, cognitive mapping, metaphors, propositional model, sense, meaning

Эмоциональное состояние человека описывают обычно в терминах эмоций и чувств. Философию здесь в основном интересует связь эмоций с человеческими потребностями и смыслом жизни; психологию - как эмоции направляют и регулируют поведение человека; этнопсихологию - национальная специфика эмоциональной сферы; эстетику - эмоциональное переживание произведений искусства, лингвистическую семантику - способы и средства отображения эмоциональности в языке. ${ }^{1}$

Обратимся непосредственно к гневу как наименее изученному, но оттого не менее значимому концепту эмоциональной сферы жизни человека с тем, чтобы установить, какие значения подводятся под гнев в русской языковой картине мира и в чем, собственно, состоит национальная его специфичность.

Симптоматика гнева является, по-видимому, сходной для всех представителей рода человеческого. В изложении психологов аффективная реакция на состояние гнева сопровождается некоординированными телодвижениями, искажением привычного выражения лица, покраснением или побледнением, особым блеском глаз, расширением ноздрей, сжиманием пальцев в кулак,

\footnotetext{
${ }^{1}$ Так объект исследования становится имманентным знанию (см. Лосский 1991: 70-73, 194).
} 
учащенным сердцебиением, пересыханием горла, дрожью в голосе, частичной или полной утратой речи. Неслучайно среди основных паттернов экспрессии гнева выделяют такие комбинации выразительных движений: 1) рот открыт - жестикулирует - кулаки сжаты - поступки необдуманные; 2) лицо искажено - глаза блестят; 3) губы и зубы плотно сжаты - глаза превращены в щели - брови резко сведены - на переносице вертикальные складки - ноздри вздрагивают; 4) кричит - жестикулирует - мечется; 5) брови резко сведены - на переносице вертикальные складки - лицо искажено; 6) глаза превращены в щели - судороги на лице - губы и зубы сжаты (ИзАРд 2002, ср. Ильин 2001).

Универсальным является, согласимся, и прототипический сценарий гнева. В изложении Дж. Лакоффа его можно представить схематически в виде таких последовательно расположенных этапов:

Этап 1. Событие, наносящее ущерб. Причиной гнева признается какоето действие или событие, расцениваемое субъектом как несправедливое, как наносящее ему ущерб и потому вызывающее у него чувство сильного неудовольствия и возмущения.

Этап 2. Гнев. Чувство гнева сопровождается двигательным возбуждением, повышением температуры тела и внутреннего давления.

Этап 3. Попытка контроля. Поскольку проявления гнева социально неприемлемы, субъект пытается сохранить самообладание, не утратить над собой контроль.

Этап 4. Потеря контроля. Когда чувство возмущения зашкаливает, субъект перестает себя контролировать.

Этап 5. Акт наказания. С утратой самоконтроля гнев избирает в качестве объекта наказания виновника причиненного ущерба (см. ЛАкОФФ 2004: 514-515).

За редким исключением внешние проявления гнева сходны по большей части для всех (или почти всех) представителей рода человеческого, чего нельзя сказать о способах его отображения в языке. Так, обратившись к тезаурусу Роже (Roget's University Thesaurus), Дж. Лакофф, в частности, отмечает, что для обозначения гнева в английском языке имеется около трехсот выражений. Причем, как показывают засвидетельствованные в тезаурусе примеры, данное психическое состояние отображается в языке либо посредством соответствующих лексико-семантических вариантов типа anger, fury и rage, либо посредством описательных оборотов типа He lost his cool 'Он потерял хладнокровие', She was looking daggers at me (букв. «Она смотрит на меня кинжалами»), I almost burst a blood vessel (букв. «У меня чуть не лопнул кровеносный сосуд») и т. п. (ЛАКОФФ 2004: 491-537).

По утверждению Дж. Лакоффа, такие обозначения не случайны, поскольку отражают сложившиеся в языке механизмы концептуализации данного психического состояния, в том числе на основе таких базовых когнитивных моделей, как пропозициональная, метонимическая и метафорическая модели. Например, пропозициональная модель, характеризующая наше знание о гневе, 
содержит пропозициональную информацию о том, что гнев сопровождается обычно покраснением лица: He was red with anger 'Он побагровел от гнева' и двигательным возбуждением: She was shaking with anger 'Ее трясло от гнева'; что гнев ослепляет: She was blind with rage 'Она была ослеплена гневом'; выводит из равновесия: He was quivering with rage 'Он дрожал от ярости'; приводит в бешенство: He got so angry, he went out of his mind 'Он настолько рассердился, что буквально обезумел'; что с гневом можно бороться: I am struggling with my anger ' $Я$ борюсь со своим гневом'; что гнев можно сдерживать и подавлять: I could barely contain my rage ' $Я$ с трудом сдерживал ярость', I suppressed my anger 'Я подавил мой гнев'; что гневу можно давать выход: I gave went my anger 'Я дал выход своему гневу' и т. д.

В заместительном типе отображения, которым характеризуется по определению метонимическая модель, на состояние гнева указывают покраснение лица и шеи: He got red with anger 'Он покраснел от злости', She was scarlet with rage 'Она стала ярко-красной от гнева'; внутреннее давление: I almost burst a blood vessel 'У меня чуть не лопнул кровеносный сосуд'; двигательное возбуждение: She was shaking with anger 'Ее трясло от гнева' и т. д.

В метафорической проекции англ. anger обозначается преимущественно в терминах жидкости, которая переполняет, бурлит и закипает в теле-сосуде: He was filled with anger 'Он был полон гнева', She was brimming with rage 'Она была переполнена яростью', You make my blood boil 'Ты заставляешь мою кровь кипеть', I had reached the boiling point 'Я достиг точки кипения'; как взрывоопасная смесь: He just exploded 'Он просто взорвался' и даже как извергаемая из вулкана лава: She erupted (букв. «Она изверглась»). Так задаются продуктивные метафорические модели типа гнев - это жар, гнев - это горение, гнев - это бурление, гнев - это кипение, гнев - это избыточное давление, гнев - это взрыв, гнев - это безумие, гнев - это противник, гнев это опасное животное, по которым структурные элементы одной предметной области представляются в терминах пропозициональной модели другой предметной области.

Как и в американском варианте английского языка, симптоматика повышенной степени раздражения отражается в русском языке через указание на двигательное возбуждение, учащенное сердцебиение, затрудненное дыхание, асфиксию, онемение, нервный тик, покраснение шеи, лица, щек и т. д.

В примерах, засвидетельствованных в Национальном корпусе русского языка (http://ruscorpora.ru), на двигательное возбуждение в состоянии гнева указывают, в частности, конвульсии и содрогания тела: Он весь затрясся om гнева (А. П. Чехов: Палата № 6, 1892); искривленное гримасой лицо: Его лицьо было искажено гневом (Г. П. Данилевский: Сожженная Москва, 1885); дрожащие губы: У меня тряслись от гнева губы, и меня винтом вертело на cmуле (С. Алешин: Встречи на грешной земле, 2001); покусывание губ: Чтоб не взорваться гневом, Прохор больно закусил губы (В. Я. Шишков: Угрюмрека, 1913-1932); сжимание и потрясание кулаками: ...nотрясает кулаками в гневе, сжимает руки у себя на груди (В. Аксенов: Коллеги, 1962); нервный 
тик: Физиономию его исказил нервный тик от гнева (В. Громов: Компромат для олигарха, 2000) и т. п.

Весьма примечательны, кроме того, и указания на изменения в цвете лица. В состоянии гнева лицо может темнеть: Гнев отемнил прекрасный лоб ее (Н. В. Гоголь: Мертвые души, 1842); чернеть: ...весь черный от гнева (Ф. В. Гладков: Повесть о детстве, 1948); мрачнеть: ...мрачный гнев лежит, как раскаленный ледяной покров на его душе (П. И. Вейнберг: Генрих Гейне. Его жизнь и литературная деятельность, 1895); покрываться красными пятнами: От гнева его рябое лицуо пошло красньли пятнами (Е. Хаецкая: Мракобес, 1997); краснеть: Ольга, красная от гнева, только открывала и закрывала рот (Д. Донцова: Доллары царя Гороха, 2004); багроветь: Багровый от гнева, он вывернул карманыл (М. А. Шолохов: Тихий Дон, 1928-1940); становиться пунцовым или иссиня-красным: ...вся пунцовая от гнева (И. А. Ефремов: Туманность Андромеды, 1956); бледнеть: ...бледный от гнева, Иванов командовал стремительной рубкой мебели (К. Г. Паустовский: Повесть о жизни. Время больших ожиданий, 1958); белеть: ...на пороге стоял бельй от гнева Иванов (К. Г. Паустовский: Повесть о жизни. Время больших ожиданий, 1958); желтеть: ...земский начальник Штрехель, пожелтев от гнева, крикнул голове и Кожемякину (М. Горький: Городок Окуров, 1909) и даже зеленеть: У девушек-красавии были позеленевшие от злости лица (Л. А. Чарская: Подарок феи, 1912); Демьян позеленел от гнева (Г. М. Марков: Строговы, 1936-1948).

Не менее показательны для симптоматики гнева и коррелирующие с глазами дескрипции. В засвидетельствованных примерах глаза в гневе блестят: Во гнев вошел, и глаза блестят, и сам дрожит, как конь во скаку (Д. А. Фурманов: Чапаев, 1923); сверкают: Глаз ее сверкнули гневом (Д. С. Мережковский: Воскресшие Боги. Леонардо да Винчи, 1901); горят: ...глаза горят гневом (Л. Дворецкий: Шакалы, 2000); темнеют: Глаза ее потемнели от гнева (К. Г. Паустовский: Книга о жизни. Далекие годы, 1946); белеют: Я увидел, как у него начинают от гнева белеть глаза (А. Приставкин: Кукушата или жалобная песнь для успокоения сердца, 1992); округляются: Глаза округляются от гнева (Л. А. Чарская: Нелюбимая, 1908); расширяются: Когда она говорила, голос ее захлебывался от возмущения, а гнев расширил зрачки... (А. Мариенгоф: Роман без вранья, 1927); сужаются: ...сразу же ощуттил ту горячую волну гнева и уколотого самолюбия, которая заливала кровью щеки и делала взгляд Юрия суженным и острым (Л. С. Соболев: Капитальный ремонт, 1932); мечут искры: ...его лицо дышиало гневом, глаза метали искры (А. Я. Панаева: Воспоминания, 1889-1890); слепнут: Векшин даже решил, что его нарочно хотят ослепить гневом, чтоб не распознал каких-то очевидных доказательств (Л. М. Леонов: Вор, 1927).

Голос в гневе дрожит: Наконеи Мраичкий, овладев собой, выговорил слегка все-таки дрожашим от гнева голосом (Е. А. Салиас: Крутоярская царевна, 1893); срывается: ...голос ее срывался от гнева (Е. С. Гинзбург: Крутой маршрут, 1975-1977); становится сдавленным: A, хорошо же! - прошептал он сдавленным от гнева голосом (В. Брагин: В стране дремучих трав, 1962); 
хрипнет: ...голосом, чуть охрипшим от внезапного гнева, проговорил Рен Боз (В. Рыбаков: Прощание славянки с мечтой, 1991); глохнет: Но вот Вальган глотнул воды, провел рукой по блестящей зыби волос, склонил разом отяжелевшую голову и другим, низким, глухим, но кипящим от гнева голосом сказал (Г. Е. Николаева: Битва в пути, 1959).

Не менее примечательны, наконец, и дескрипции, связанные с дыханием: Oн задыхался от гнева (А. И. Куприн: Конокрады, 1903); сердцебиением: ...его охватил гнев, сердцебиение усилилось (Ю. Трифонов: Дом на набережной, 1976); утратой дара речи: ...я от гнева онемела (Д. Донцова: Доллары царя Гороха, 2004).

В соответствии со сложившимся в культуре сценарием пропозициональная модель содержит пропозициональную информацию о том, что в гнев впадают: A, так ты с ним заодно? - впадая в гнев, прокричал Иван (М. А. Булгаков: Мастер и Маргарита, 1929-1940); что гнев овладевает: Мною овладел редко случавиийся приступ гнева (Р. М. Фрумкина: О нас - наискосок, 1995); что гневу дают волю: Дима молча проводил его до гостиницьы и только тут дал волю своему гневу (А. Слаповский: Гибель гитариста, 1994-1995); на комто срывают: Он любил сорвать на ком-нибудь гнев (Н. Г. Помяловский: Молотов, 1861); вымещают: Он всего лишь накричал на подчиненного, выместил на нем гнев (Г. Я. Бакланов: Июль 41 года, 1964); что гнев можно вызвать: Сердюков заметил, что супруга старалась вызвать в себе прилив гнева, чтобы с новой силой выплеснуть его наружу (С. Романов: Парламент, 2000); навлечь: ...без страха отдаю отчет в делах моих и уверена, что они не привлекут на меня гнева его (Неизвестный: Истинное приключение благородной россиянки, 1803); мобилизовать: Партия мобилизует обычно гнев масс, ярость, нацеливает бить врага (В. Гроссман: Жизнь и судьба, 1960); умерить: Я прошу тебя только об одном, - продолжал Эдмон, - умерить гнев свой (Н. П. Брусилов: Легковерие и хитрость, 1806); утолить: ...думала Марья Дмитриевна, стараясь утолить свой гнев (Л. Н. Толстой: Война и мир, 1867-1869); обуздать: Но я сумел обуздать свой гнев (О. Новикова: Мужской роман, 1999); укротить: Пришлось напрячься, собрать всю волю и укротить недоброе клокотание гнева (Б. Окуджава: Путешествие дилетантов, 1971-1977); усмирить: Привычная работа так усмирила гнев, что понадобилось поковырять в ране, повспоминать только что разразившуюся ссору, чтобы раж уж совсем не испарился (О. Новикова: Мне страшно, или Третий роман, 2003); сменить на милость: Ксения Федоровна сменила гнев на милость (А. Варламов: Купавна, 2000); что от гнева темнеет в глазах: $O m$ гнева потемнело в глазах (Р. Солнцев: Полураспад. Из жизни А. А. Левушкина Александрова, а также анекдоты о нем, 2000-2002); что от гнева краснеют: ...все еще красный от гнева (Б. В. Савинков: То, чего не было, 1912); бледнеют: побледневщее от гнева лицо Зинь (А. В. Амфитеатров: Княжна, 1889-1895); задыхаются: ...задохнулся от гнева (Е. Лукин: Катали мы ваше солнце, 1997); трепещут: Он узнал меня - и залился слезами; произнес твое имя - и затрепетал от гнева (Н. Мамышев: Злосчастный, 1807); что гнев 
застилает глаза: Гнев накатыввет такой, что застилает глаза (М. Магомаев: Любовь моя - мелодия, 1999); ослепляет: Боюсь, что ослеплена гневом и поэтому очень несправедлива (Б. Васильев: Были и небыли, 1988); туманит голову: Гнев туманил мне голову (Н. Климонтович: Дорога в Рим, 1991-1994); распирает: ...гнев распирает его настолько, что, не будь тут стола, он бь схватился с начальником «Восточного плеча» врукопашную (Ю. В. Трифонов: Утоление жажды, 1970); растет и ширится: Гул гнева растет и ширится (3. И. Воскресенская: Сердце матери, 1963-1965); переполняет: Страшный черный гнев переполняет тогда Алексея Петровича, он сверкает глазами, брызжет слюной, забывает слова, огненные пятна прыгают перед взором, он может задушить, разорвать в клочья! (Т. Толстая: Ночь, 1983); рвется наружу: ...и гнев ее так и рвался наружу (Н. А. Лухманова: Девочки, 1894); мутит рассудок: Багровый гнев помутил рассудок и текучим свинцом налил руки (М. А. Шолохов: Батраки, 1928); сводит с ума: ...cmыл, гнев сводят меня с ума (А. В. Амфитеатров: Жар-цвет, 1895); доводит до беспамятства: В гневе доходил до беспамятства (М. А. Шолохов: Тихий Дон, 1928-1940); приводит в бешенство: Ленусик стонала и плакала, жаловалась и, не находя сочувствия, взрывалась бешенством и гневом (Е. Маркова: Тайная вечеря, 1990-2000); вызывает ужас: Нарастаюший ужас перед истребительной силой государственного гнева, все растущее чувство одиночества, беспомощности, иьыплячьего жалкого бессилия, обреченности, - все это порождало в нем минутами какую-то отчаянность, разухабистое безразличие к опасности, презрение к осторожности (В. Гроссман: Жизнь и судьба, 1960) и т. д.

В метафорическом отображении рус. гнев переосмысливается в зависимости от избираемой по случаю установки мнения и в терминах некоего исчисляемого ресурса, который накапливается, растрачивается и иссякает, и в терминах некоей неподвластной человеку враждебной силы, которая приводит в ужас, овладевает и душит, и в терминах дикого животного, которого можно обуздать, укротить или спустить с цепи, и в терминах водной стихии, которая бушует, захлестывает и выходит из берегов, и в терминах пожара, который разгорается, пылает и затухает. ${ }^{2}$ Причем для интерпретирующей семантики здесь важно даже не установить, соответствует ли такое представление истинному положению вещей, а понять, почему в качестве вспомогательного объекта метафорической транспозиции в русской языковой картине мира избирается такой, а не какой-либо другой объект, и насколько узуальным является данный способ представления.

Остановимся подробнее на наиболее показательных случаях.

В метафорической проекции рус. гнев переосмысливается нередко в терминах жидкости с вместилищем в виде таких частей тела-сосуда, как сердце: переполненное гневом сердие (К. М. Станюкович: Беспокойный адмирал,

\footnotetext{
${ }^{2}$ Используя термины А. А. Потебни, можно заключить: «объясняющему образу, имеющему субъективное значение, приписывается объективность, действительное бытие в объясняемом» (ПотЕБНЯ 1976: 432-433).
} 
1894); грудь: Гнев кипел у него в груди (М. Милованов: Естественный отбор, 2000); живот: Гнев начал подниматься во мне откуда-то снизу живота... (Г. Садулаев: Когда проснулись танки, 2010); душа: гнев подпирал под самую душу (А. Н. Толстой: Мишука Налымов, 1909).

В избираемой по случаю установке мнения отбору соответственно подлежат предикатные дескрипции: закипать: Он каждый раз вдруг закипал таким гневом (Ю. Н. Тынянов: Пушкин, 1935-1943); вскипать: Вскипел гневом владыка ордынский (Н. С. Лесков: Чертовы куклы, 1890); кипеть: ...ярость и гнев и кипели на сердце (П. И. Мельников-Печерский: На горах, 1875-1881); бурлить: Во мне бурлит гнев (А. Мариенгоф: Циники, 1928); наливаться: Продавщчица его давно заметила и теперь, наливаясь гневом, ждет, когда он подъедет поближе (Ф. Искандер: Бедный демагог, 1969); наполнять: Врач раскачивался на стуле, а Ольгу все наполнял гнев (Г. Щербакова: Армия любовников, 1997); переполнять: Страшный черный гнев переполняет тогда Алексея Петровича (Т. Толстая: Ночь, 1983); изливаться: ...ему нужно было излить свой гнев (А. К. Шеллер-Михайлов: Лес рубят - щепки летят, 1871); выливаться: ....теперь более спокойный и смягченный, точно Шульгович уже успел вылить свой гнев в крике и удовлетворил свою жажду власти видом чужжого унижения (А. И. Куприн: Поединок, 1905); расплескиваться: Он поспешно оделся $и$, как бы неся полную чашу гнева и боясь расплескать ее, боясь вместе с гневом утратить энергию, нужную ему для объяснения с женою, вошел к ней, как только узнал, что она встала (Л. Н. Толстой: Анна Каренина, 1878); иссякать: В конце концув гнев иссяк (К. Сурикова: Аутсайдерский романчик, 2003) и т. д.

Не менее показательны, со своей стороны, и отображения гнева в терминах природной стихии: прилива: ...лицуо его на мгновение исказилось от прилива гнева (Е. А. Салиас: Крутоярская царевна, 1893); волны: волна гнева заливала его и несла, в стремительном своем беге, в темной пучине инстинкma (А. С. Грин: Трагедия плоскогорья Суан, 1912); вихря: Вихрь его гнева в эту минуту мог смести кого угодно (И. Полянская: Жизель, 1996); бури: ...кто вызвал в нем только что бурю гнева (Э. Любарский: Бедственная экспедиция, 1894); огня: Гнев, - соображал он, - прогневаться, огневаться, вот он откуда, гнев, - из огня! (М. Горький: Жизнь Матвея Кожемякина, 1910); пламени: ...вся занявшаяся темным пламенем гнева, воистину прекрасная в своем простодушном раздражении (Ф. К. Сологуб: Капли крови [Навьи чары], 1905); тучи: Помню сизые тучи голубей и черную - народного гнева (М. И. Цветаева: Нездешний вечер, 1936); грозы: ...на нее обрушилась страшная гроза гнева князя (Л. Н. Толстой: Война и мир, 1867-1869); грома: Во гневе гром ее ужасен (И. А. Крылов: Почта Духов, или Ученая, нравственная и критическая переписка арабского философа Маликульмулька с водяными, воздушными и подземными духами, 1789); молнии: И молнии гнева в очах цุаря повергали людей на землю (А. И. Куприн: Суламифь, 1908).

В соответствии с заданной установкой мнения совершается в диапазоне допустимого варьирования и отбор предикатных дескрипций. 
В качестве водной стихии, потока, прилива или волны, гнев может пениться: В пене гнева стонут волны (М. Горький: Песня о Буревестнике, 1901); приливать: ...краска гнева опять приливала к лицу и вискам молодой женщинны (В. Г. Короленко: Слепой музыкант, 1886-1898); заливать: ...и теперь уже не бледность заливала его щеки, а темная просинь гнева (М. А. Шолохов: Поднятая целина, 1958); затапливать: А тут лишь гнев, такой обильный, затапливающий (К. Сурикова: ДТП, 2003); захлестывать: Волна гнева захлестылвала его так же неожиданно, как и вскоре незаметно спадала (А. Ростовский: По законам волчьей стаи, 2000); клокотать: ...гнев клокотал в ней (В. Ф. Панова: Времена года. Из летописей города Энска, 1953); бушевать: Там, где недавно бушевали гнев, раскаяние, злоба, любовь, было пусто... (И. Грекова: Фазан, 1984); входить в берега: ...буйный гнев вошел в берега (Д. А. Фурманов: Мятеж, 1924).

В качестве огненной стихии, огня, пламени или пожара, гнев может разжигаться: ...желая еще пуще разжечь его гнев, Илько с видом угнетенной невинности начал бормотать (К. И. Чуковский: Солнечная, 1936); загораться: и глаза загорелись гневом (П. И. Мельников-Печерский: На горах, 18751881); разгораться: ...лицчо разгоралось гневом (А. А. Бестужев-Марлинский: Вадимов, 1834); вспыхивать: ...в глазах ее вспьхивает гнев (А. А. Богданов: Варвара, 1912); гореть: ... глаза горели гневом (А. Ф. Писемский: Русские лгуны, 1865); пылать: Всегда такое спокойное, слегка насмешливое и твердое, оно теперь пылает гневом (А. И. Куприн: Изумруд, 1907); полыхать: ...глаза польхали гневом (С. Романов: Парламент, 2000); пламенеть: ...глаза пламенеют от гнева и стыла за мать (А. Н. Вербицкая: Ключи счастья, 1909); обжигать: Теперь его уносил, удушая и обжигая, самый страшный гнев, гнев бессилия (М. А. Булгаков: Мастер и Маргарита, 1929-1940); опалять: Погоди! - зашептал Григорий, опаляемый гневом (М. А. Шолохов: Тихий Дон, 1928-1940); испепелять: ...огонь небесный испепелил Москву (А. К. ШеллерМихайлов: Дворец и монастырь, 1900); гаснуть: Гнев погас в темных глазах Рублева (А. Н. Толстой: Хождение по мукам, 1928).

По аналогии с диким животным гнев можно укротить: Пришлось напрячься, собрать всю волю и укротить недоброе клокотание гнева (Б. Окуджава: Путешествие дилетантов, 1971-1977); обуздать: Видимо, гнев был успешно обуздан (Н. Леонов, А. Макеев: Ментовская крыша, 2004); придержать: ... решил, видимо, пока попридержать свой гнев (Е. Белкина: От любви до ненависти, 2002); спустить с цепи: ...ггев людской спустить, как цепного кобеля (М. А. Шолохов: Тихий Дон, 1928-1940); усмирить: Привычная работа так усмирила гнев, что понадобилось поковырять в ране, повспоминать только что разразившуюся ссору, чтобы раж уж совсем не испарился... (О. Новикова: Мне страшно, или Третий роман, 2003).

Разумеется, в условно-истинностном исчислении метафорические дескрипции вида усмирить гнев или закипать в гневе представляются неприемлемыми и даже, можно сказать, ложными по сравнению с дескрипцией вида прийти в повышенное состояние раздражения. Но если о соответствии при- 
соединенного предиката судить по засвидетельствованному в речевом обиходе употреблению, о сообразности пропозиции следует тогда судить только и только по тому, насколько узуальным является такое словоупотребление. Больше того, подобное понимание гнева укореняется в обыденном сознании насколько, что носители языка не обращают более внимания на метафоричность выражений вида взорваться от гнева или обуздать свой гнев, а принимают их чуть ли не за объективную характеристику того, чем является «на самом деле» гнев. Это значит, что модельная структура, по которой определяется эмоциональное состояние человека, является этим состоянием; и не существует более различия между объективным представлением и соответствующим его отображением в языке. Аргументом в пользу такого представления, а заодно и интерпретантом метафорического отношения, становится если не абсолютно истинное, то хотя бы не подлежащее сомнению мнение, что при потере хладнокровия кровь закипает, что от возмущения можно взорваться, что гнев укрощают, как укрощают дикое животное и т. п.

В заключение сформулируем следующие выводы:

1. Определять содержание эмоционального концепта можно, разумеется, и путем аппроксимации к собственному переживанию, сопоставленному с другими подобными переживаниями, но утверждать, каким является его содержание в языке, можно только по засвидетельствованному в речевом обиходе словоупотреблению.

2. Симптоматика состояния гнева отображается в языковом выражении через указание на двигательное возбуждение, содрогания тела, изменения в цвете лица, учащенное сердцебиение, затрудненное дыхание и т. п.

3. Сообразно типовому сценарию пропозициональные установки, задающие наше знание о гневе, содержат информацию о том, что гнев на ком-то срывают, что гнев выводит из равновесия, приводит в бешенство, доводит до безумия, ослепляет, душит и т. п.

4. В метафорической проекции рус. гнев определяется в терминах пропозициональной модели других предметных областей, в том числе «жидкость», «водный поток», «молния», «гром», «пожар», «дикие животные», о чем свидетельствуют с очевидностью присоединенные предикаты вида переполнять (жидкость), испепелять (огонь), обуздать (животное) и т. п.

5. От выбора метафорической дескрипции зависит вкладываемый в высказывание смысл.

6. Интерпретантом метафорического определения вида гнев - это огонь или гнев - это дикое животное служат общепринятые мнения и представления $(\operatorname{doxa})$ в функции прагматической пресуппозиции.

7. Взяв за достаточное основание суждений мнение, нельзя не пересмотреть кардинальным образом критерий верификации истинностного значения суждений. В системе общих мнений и представлений (doxa) это соответствие тому, во что верит или с чем соглашается независимо от реального положения вещей большинство представителей данного языкового сообщества. 


\section{Литература}

ИзАРд 2002 = ИзАРД К. Э. Психология эмоиий. Санкт-Петербург: «Питер», 2002. Ильин 2001 = Ильин Е. П. Эмоции и чувства. Санкт-Петербург: «Питер», 2001.

ЛАКОФФ 2004 = ЛАКОФФ ДЖ. Женщины, огонь и опасные вещчи. Что категории языка говорят нам о мылилении. Москва: «Языки славянской культуры», 2004.

Лосский 1991 = Лосский Н. О. Обоснование интуитивизма. В кн.: Лосский Н. О. Избранное. Москва: «Правда», 1991. 13-334.

ПотЕБНя 1976 = ПотЕБНя А. А. Эстетика и поэтика. Москва: «Искусство», 1976. 